\title{
Arterial osteoprotegerin: increased amounts in diabetes and modifiable synthesis from vascular smooth muscle cells by insulin and TNF- $\alpha$
}

Received: 10 May 2004 / Accepted: 8 October 2004 / Published online: 8 February 2005

(C) Springer-Verlag 2005

\begin{abstract}
Aims/hypothesis: Extracellular matrix modifications and linear medial calcifications are elements of diabetic macroangiopathy. We hypothesised that the bonerelated protein osteoprotegerin (OPG) may occur in altered amounts in the arterial wall in diabetes, putatively associated with altered synthesis from vascular cells. Methods: The amount of OPG in the thoracic aorta, obtained at autopsy from 21 diabetic and 42 sex- and age-matched controls, was measured in tissue extracts by an ELISA. The production of OPG was estimated in conditioned media by an ELISA, and OPG mRNA was estimated by RT-PCR in vascular cells grown in vitro. Results: The content of OPG was increased in tunica media samples from diabetic individuals. No differences between diabetic and non-diabetic subjects were observed in tunica intima. Human vascular smooth muscle cells (HVSMCs) produced approximately 30 times more OPG than human umbilical vein endothelial cells. The OPG production into the medium decreased dose- and timedependently after insulin treatment (maximal effect $\sim 60 \%$ of control) in HVSMCs, whereas TNF- $\alpha$ supplement gave rise to increased OPG synthesis in a time- and dosedependent manner (maximal effect $200 \%$ of control). Similar effects on OPG mRNA expression were observed. Addition of growth hormone $(10 \mathrm{ng} / \mathrm{ml})$ or extra glucose $(25$ $\mathrm{mmol} / \mathrm{l}$ ) to the growth medium had no effect. Conclusions/ interpretation: Increased OPG concentrations in the arterial wall in diabetes may be part of generalised matrix alterations, putatively related to the development of vascular calcifications. Altered arterial OPG content may be a con-
\end{abstract}

P. Olesen · T. Ledet · L. M. Rasmussen

Research Laboratory for Biochemical Pathology,

Institute of Pathology, Aarhus University Hospital,

Aarhus, Denmark

L. M. Rasmussen $(\bowtie)$

Department of Clinical Biochemistry, Aarhus Sygehus,

Aarhus University Hospital,

Tage-Hansensgade 2,

8000 Aarhus C, Denmark

e-mail: 1mr@dadlnet.dk

Tel.: +45-89493050

Fax: $+45-89497035$ sequence of the effects of hormones and cytokines, like insulin and TNF- $\alpha$.

Keywords Angiopathy · Atherosclerosis - Endothelial cells · Insulin - Osteoprotegerin - Smooth muscle cells · TNF- $\alpha$

Abbreviations $\mathrm{GnHCl}$ : Guanidium $\mathrm{HCl}$ - HVSMCs: Human vascular smooth muscle cells - OPG:

Osteoprotegerin - RANKL: Receptor activator of nuclear factor- $\mathrm{KB}$ ligand

\section{Introduction}

The high incidence of cardiovascular diseases in diabetes may, at least partially, be due to the presence of diabetic macroangiopathy as a fertile soil for atherogenesis [1]. Several potentially pre-atherosclerotic alterations delineate the macroangiopathy, which comprises histomorphometric changes [2], matrix alterations [3, 4], accumulation of glycated proteins [5], endothelial dysfunction [6], altered biomechanical properties [7] and medial calcifications [8].

Medial artery calcifications have frequently been observed in diabetes and are related to the degree of glucose intolerance [8] and to the presence of neuropathy [9]. Two prospective studies have shown that the occurrence of medial artery calcifications in type 2 diabetes is a strong independent predictor of cardiovascular mortality $[10,11]$. The medial calcifications are not believed to play independent pathophysiological roles but may be markers for the presence of generalised arterial changes in diabetes. However, the causative relations behind the association between medial artery calcifications and cardiovascular disease are not known. Moreover, the pathogenetic mechanisms leading to the calcifications are enigmatic, but have been suggested to relate to the presence of generalised arterial matrix alterations in diabetes [12].

Some of the molecular mechanisms operating in the processes of vascular calcifications, in general, have been unravelled during the last few years. The expression of 
bone- and cartilage-related extracellular matrix proteins in arterial tissue seems to play a pivotal role [13, 14], since experimental modulations of the amounts of matrix-Glaprotein and osteopontin in the arterial wall have led to severe generalised vascular calcifications $[14,15]$. It is therefore of great interest that a few studies seem to indicate that accumulation of bone- and cartilage-related molecules, i.e. osteopontin [16], hyaluronic acid [17] and bone-Glaprotein [18], occurs in the arterial wall in human diabetes. Similar findings of accumulation of bone- and cartilagerelated gene products have been described in animals with experimentally induced conditions, mimicking type 2 diabetes $[19,20]$, but the data in this research field are still limited.

Osteoprotegerin (OPG) is a recently described bonerelated molecule that inhibits osteoclast differentiation and therefore displays anti-bone-resorptive activity [21]. OPG is a secreted member of the TNF-R family and it exerts its effect through binding and neutralisation of receptor activator of nuclear factor- $\mathrm{kB}$ ligand (RANKL), a strong inducer of osteoclast differentiation [21]. An experimental study has shown that OPG is also present in the arterial wall [22], but the function of OPG in the vasculature is not clear. The bone-related OPG ligand RANKL is not present [22], at least not in normal arteries. However, experimental studies have suggested that OPG may nonetheless work as an inhibitor of vascular calcifications, since mice, genetically engineered to lack OPG, develop arterial calcium deposits [23]. Alternatively, the apparent impact of OPG on arterial calcifications may be mediated through secondary effects due to severe osteoporosis in the OPG knock-out mice, as suggested by Price et al. [24]. Both vascular smooth muscle cells [25] and endothelial cells [26] have been shown to produce OPG in vitro, but only a few details are known about its regulation. In addition to the localisation of OPG in bones and vasculature, the molecule circulates in small amounts in plasma, and interestingly, three independent studies have reported increased amounts in patients with diabetes [27-29].

In the present investigation, we measured the amount of OPG in arterial tissue from diabetic and non-diabetic individuals. Moreover, we analysed the production of this molecule from vascular cells and determined whether insulin, growth hormone, glucose and TNF- $\alpha$ influence its secretion.

\section{Materials and methods}

Aortas This study is based on examinations of mid-thoracic aortic samples, obtained from autopsy vessels, that were analysed in a previously published investigation [4]. The descending part of the aorta was collected from nine type 1 diabetic individuals and 12 type 2 diabetic individuals, as well as from two groups of sex- and age-matched control persons (Table 1). The tissue was separated into areas with and areas without visible fibrous atherosclerotic plaques and dissected further into intima and media specimens [4]. Areas of the tissue with faint yellow intima without ele-
Table 1 Patient characteristics

\begin{tabular}{|c|c|c|}
\hline & $\begin{array}{l}\text { Diabetic } \\
\text { individuals }\end{array}$ & $\begin{array}{l}\text { Non-diabetic } \\
\text { individuals }\end{array}$ \\
\hline Number & 21 & 42 \\
\hline Age $\left(\right.$ years) ${ }^{\mathrm{a}}$ & $66 \pm 12$ & $67 \pm 12$ \\
\hline $\operatorname{Sex}(F / M)$ & $7 / 14$ & $14 / 28$ \\
\hline \multicolumn{3}{|l|}{ Cause of death } \\
\hline Cardiovascular $^{\mathrm{b}}$ & 14 & 20 \\
\hline Neoplasia & 4 & 11 \\
\hline Other $^{c}$ & 3 & 11 \\
\hline $\begin{array}{l}\text { Diabetes type } \\
\text { (type } 1 / \text { type } 2 \text { ) }\end{array}$ & $9 / 12$ & \\
\hline $\begin{array}{l}\text { Duration of diabetes } \\
\text { (years) }^{\text {a }}\end{array}$ & $21 \pm 14$ & \\
\hline
\end{tabular}

${ }^{\mathrm{a}}$ Means \pm SD

${ }^{\mathrm{b}}$ Acute myocardial infarction, cardiac insufficiency and stroke

${ }^{\mathrm{c}}$ Infections, accidents, etc.

vations were considered to be non-atherosclerotic, whereas regions with elevated white areas without ulcerations, aneurysm or thrombosis were considered to be uncomplicated fibrous plaques. Separation of tissue was confirmed by microscopy of several specimens [4]. Samples were lyophilised, defatted by chloroform-ethanol (3:1) treatment, dried, and pulverised in a Retsch Mill. All samples had been stored at $-80^{\circ} \mathrm{C}$ for several years. Analysis of the tissue was approved by the local ethics committee.

Tissue extraction and quantitation of total protein and calcium In pilot experiments, pools of defatted, dried, and pulverised aortic tissue were extracted using $2 \mathrm{ml}$ of one of the following: (1) $2 \mathrm{~mol} / \mathrm{l}$ guanidium $\mathrm{HCl}(\mathrm{GnHCl})$ in $\mathrm{PBS}$, $\mathrm{pH} 7.4$; (2) $2 \mathrm{~mol} / \mathrm{l}$ urea in PBS, pH 7.4; (3) $1 \mathrm{~mol} / \mathrm{l} \mathrm{NaCl}$ in $10 \mathrm{mmol} / 1$ phosphate, $\mathrm{pH} 7.4$; (4) $1 \%$ Triton X-100 in PBS,

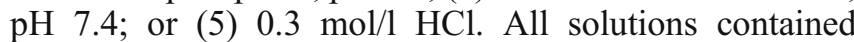
protease inhibitors $(0.5 \mathrm{mmol} / \mathrm{l}$ ethylmaleimide, $0.5 \mathrm{mmol} / \mathrm{l}$ phenylmethylsulphonyl fluoride, $1 \mathrm{mmol} / 1$ benzamidine) and extraction was done for $24 \mathrm{~h}$ with constant magnetic stirring at $4^{\circ} \mathrm{C}$. Extracts were cleared by centrifugation at $10,000 \times \mathrm{g}$ for $20 \mathrm{~min}$ at $4^{\circ} \mathrm{C}$. Protein content in the extracts was determined by Micro BCA protein assay from Pierce, using bovine serum albumin as standard. The determination of calcium was done as described for bone tissue [30]. Next, 5 to $10 \mathrm{mg}$ arterial powder was hydrolysed in $1 \mathrm{~mol} / \mathrm{l}$ $\mathrm{HCl}$ for $48 \mathrm{~h}$. Calcium was subsequently measured in cleared supernatants by a coulometric (o-cresolphthalein) method from Sigma (587-A).

Cultures of endothelial and vascular smooth muscle cells Human vascular smooth muscle cells (HVSMCs) were established from explants of normal aortic tissue, obtained from excess donor vasculature at kidney transplantations [31]. Human umbilical vein endothelial cells (HUVECs) were obtained from collagenase-digested umbilical veins, as previously described [32]. HVSMCs were maintained in minimal essential medium (Invitrogen) containing 10\% newborn calf serum, while HUVECs were grown in DMEM 
Fig. 1 Aortic OPG concentrations. Grey bars are results from diabetic individuals and black bars are results from non-diabetic individuals. "Intima" and "Media" indicate specimens from these arterial compartments whereas "Normal" are results from areas of the vessels that appeared macroscopically normal and "Plaque" are results from areas that displayed fibrous plaques. Results are presented as means \pm SEM. ${ }^{*} p<0.05$ and $* * p<0.01$ vs non-diabetic group

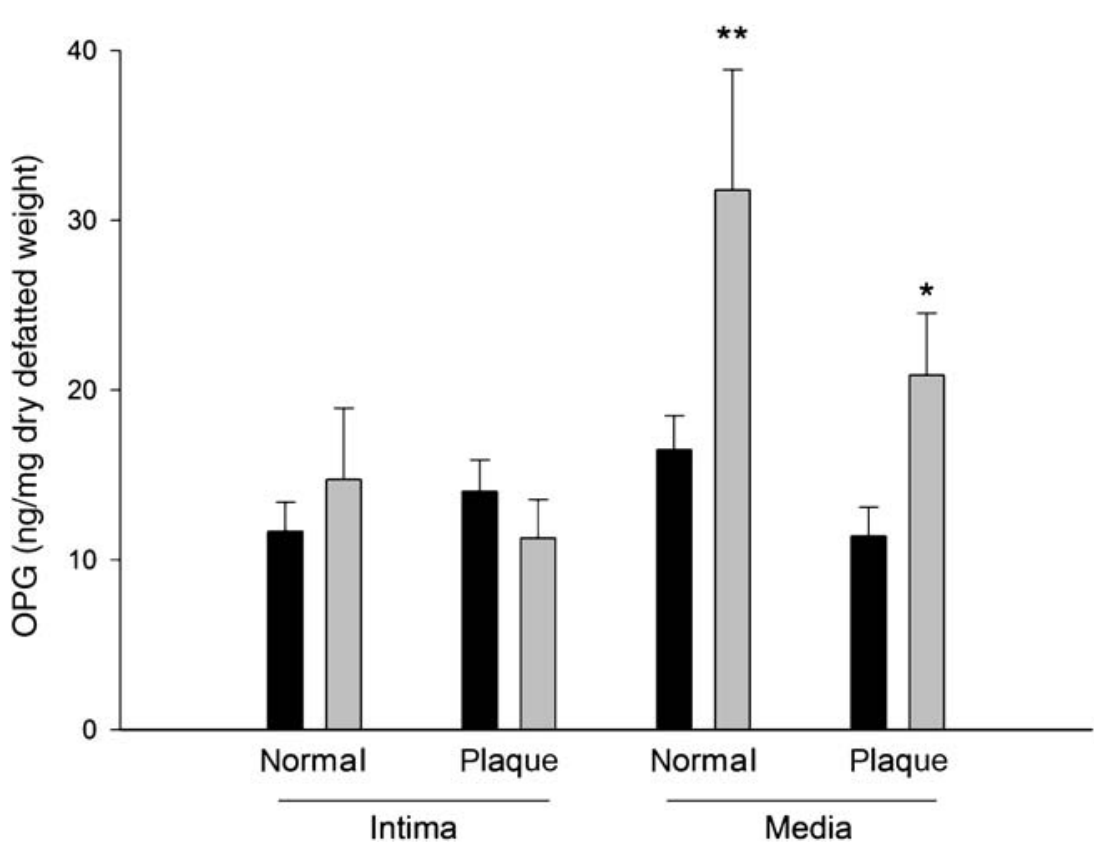

(Invitrogen), $10 \%$ fetal bovine serum, $40 \mu \mathrm{g} / \mathrm{ml}$ endothelial cell growth factor, and $15 \mathrm{U} / \mathrm{ml}$ heparin. Endothelial cells were grown on gelatin-coated plates $\left(0.65 \mu \mathrm{g} / \mathrm{cm}^{2}\right)$. All media contained $50 \mu \mathrm{g} / \mathrm{ml}$ gentamicin sulphate, $2 \mu \mathrm{g} / \mathrm{ml}$

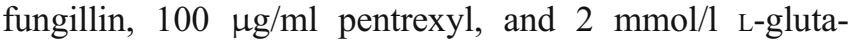
mine, and the cells were maintained at $37^{\circ} \mathrm{C}$ in an atmosphere of $5 \% \mathrm{CO}_{2}, 95 \%$ atmospheric air. The cells were subcultured after detaching with trypsin solution and replating. Cell counts were performed after trypsination using a Bürker-Türk chamber. The production of OPG was determined in experiments where cells were seeded at a density of $6,000 / \mathrm{cm}^{2}$ and left for a few days, at which time the cultures were confluent. Two designs were used: in one type, the accumulation of OPG in conditioned media was measured after incubation for $24 \mathrm{~h}$. In other experiments, OPG production per hour was estimated using cells treated with test substance for various time periods and then washed with prewarmed $\left(37^{\circ} \mathrm{C}\right)$ PBS and left for $1 \mathrm{~h}$ with growth medium at $37^{\circ} \mathrm{C}\left(5 \% \mathrm{CO}_{2}\right)$ without serum and test substance. OPG was subsequently measured in these media. The growing of cells was approved by the local ethics committee.

Osteoprotegerin ELISA OPG was measured in diluted extracts and in conditioned growth media by a sandwich ELISA using commercially available antibodies for this purpose (R\&D Systems, Minneapolis, MN, USA; cat. no. DY805). Microtitre wells were coated with $2 \mu \mathrm{g} / \mathrm{ml}$ of a mouse monoclonal antibody for catching, and detection was done with $50 \mathrm{ng} / \mathrm{ml}$ of a biotinylated goat antibody. Recombinant human OPG was used as a standard. Streptavidin-horseradish peroxidase was used for detection of bound biotinylated immunoglobulin, and tetramethylbenzidine was added as substrate. Colouring was stopped after $20 \mathrm{~min}$ with $2 \mathrm{~mol} / \mathrm{l}$ sulphuric acid and wells were read at $450 \mathrm{~nm}$.
OPG was estimated in individual aortic pulverised samples $(5-10 \mathrm{mg})$ extracted with $2 \mathrm{~mol} / \mathrm{l} \mathrm{GnHCl}$ in dilutions of 1:100. After optimisation, all extracted samples (in random order) were analysed in one analytical run in the ELISA.

RNA isolation and quantitative RT-PCR Total RNA was extracted and isolated from cells using Trizol (Roche, Denmark; $0.5 \mathrm{ml}$ per cell culture well) and quantified by spectrophotometry at 260 and $280 \mathrm{~nm}$. First-strand cDNA was synthesised from $1 \mu \mathrm{g}$ RNA by incubating with 200 U Moloney murine leukaemia virus reverse transcriptase (Gibco-BRL/ Life Technologies, Roskilde, Denmark) in a 30- $\mu$ l reaction mixture containing $50 \mathrm{mmol} / \mathrm{l}$ Tris $(\mathrm{pH} 8.3), 75 \mathrm{mmol} / \mathrm{l}$ $\mathrm{KCl}, 3 \mathrm{mmol} / 1 \mathrm{MgCl}_{2}, 0.5 \mathrm{mmol} / \mathrm{ldATP}, 0.5 \mathrm{mmol} / \mathrm{l} \mathrm{dTTP}$, $0.5 \mathrm{mmol} / 1 \mathrm{dGTP}, 0.5 \mathrm{mmol} / \mathrm{ldCTP}$ and $30 \mathrm{pmol}$ of random hexamers for $75 \mathrm{~min}$ at $37^{\circ} \mathrm{C}$, followed by $15 \mathrm{~min}$ at $95^{\circ} \mathrm{C}$.

Table 2 Aortic OPG and calcium content

\begin{tabular}{|c|c|c|c|c|}
\hline & $\begin{array}{l}\text { Type } 1 \\
\text { diabetes }\end{array}$ & Control & $\begin{array}{l}\text { Type } 2 \\
\text { diabetes }\end{array}$ & Control \\
\hline \multicolumn{5}{|c|}{ OPG (ng/mg dry defatted weight) } \\
\hline Normal intima & $19.2 \pm 7.1$ & $12.8 \pm 2.9$ & 2.3 & $10.6 \pm 1.9$ \\
\hline Plaques in & 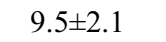 & $14.1 \pm 3.3$ & 12.5 & $14.0 \pm 2.9$ \\
\hline Norma & $46.8 \pm 13.0^{\mathrm{a}}$ & $14.4 \pm 2.4$ & $20.5 \pm 3.4$ & $18.0 \pm 2.9$ \\
\hline Plaques me & $21.6 \pm 7.6^{\mathrm{b}}$ & 10 & $20.4 \pm 3.9^{c}$ & $12.2 \pm 2.0$ \\
\hline \multicolumn{5}{|l|}{ Calcium $(\mu \mathrm{g} / \mathrm{mg})$} \\
\hline Normal intima & $5.6=$ & 0.5 & $11.7 \pm 4.5$ & $5.9 \pm 1.0$ \\
\hline Pla & $49.0=$ & 37.0 & $20.1 \pm 4.6$ & $33.5 \pm 8.3$ \\
\hline Normal & $18.9 \pm 3.8$ & & $11.9 \pm 2.0$ & $15.1 \pm 3.0$ \\
\hline Plaques media & $17.8 \pm 3.7$ & $13.8 \pm 2.8$ & $10.6 \pm 2.1$ & $11.5 \pm 2.5$ \\
\hline
\end{tabular}

All values are means \pm SEM.

${ }_{p}^{\mathrm{a}}<0.01$ vs control groups

${ }^{\mathrm{b}} p=0.1$ vs control groups

${ }^{c} p<0.05$ vs control groups 
PCR was performed using $2 \mu \mathrm{l}$ RT solution in a reaction mixture of $25 \mu$ using the iQ SYBR Green Supermix (BioRad, Hercules, CA, USA) containing $20 \mathrm{mmol} / \mathrm{l}$ Tris (pH 8.4), $50 \mathrm{mmol} / 1 \mathrm{KCl}, 1.5 \mathrm{mmol} / 1 \mathrm{MgCl}_{2}, 0.2 \mathrm{mmol} / 1 \mathrm{dATP}$, $0.2 \mathrm{mmol} / 1 \mathrm{dTTP}, 0.2 \mathrm{mmol} / 1 \mathrm{dGTP}, 0.2 \mathrm{mmol} / 1 \mathrm{dCTP}, 3$ $\mathrm{mmol} / 1 \mathrm{MgCl}_{2}, 20 \mathrm{nmol} / \mathrm{l} \mathrm{SYBR}$ Green I fluorescein and 25 $\mathrm{U} / \mathrm{ml}$ iTaq DNA polymerase (final concentrations). PCR was performed with two primer sets, specific for human OPG and for human $\beta$-actin. PCR was done with real-time detection using the Bio-Rad iCycler iQ system (Bio-Rad). The fluorescence threshold value was calculated using the iCycle iQ system software. Each PCR run included a tenfold serial dilution of a sample with a high RNA content. The results from these dilutions were used to translate sample-threshold values to linear arbitrary units. Moreover, the efficiency of the PCR amplifications could be calculated from these dilution curves. The efficiency was above $98 \%$ in all PCR procedures. OPG results are expressed as the ratio of OPG mRNA units/ $\beta$-actin mRNA units.

Statistical analysis All results are expressed as means \pm SEM. Differences between groups were tested by ANOVA and Student's $t$-test. A two-tailed $p$ value of less than 0.05 was considered significant.

\section{Results}

Preliminary experiments with pools of pulverised aortic tissue showed that solutions containing $\mathrm{GnHCl}$ extracted OPG twice as effectively as all other attempted extraction conditions (data not shown). Furthermore, we found that aortic $\mathrm{GnHCl}$ extracts in the ELISA procedure diluted parallel to standard curves of recombinant human OPG in a range of 1:100-1:2,000. The recovery of $500 \mathrm{pg} / \mathrm{ml}$ exogenously added $\mathrm{OPG}$ to $\mathrm{GnHCl}$ extracts, diluted 1:100, was $85 \pm 4 \%(n=3)$.

Fig. 2 OPG production from HVSMCs. Effects of $24 \mathrm{~h}$ of incubation with TNF- $\alpha(T N F)$, insulin (Ins) or growth hormone $(G H)$ using the indicated concentrations. Results are means \pm $\operatorname{SEM}(n=8) .{ }^{* *} p<0.01$ vs cells without added substances $(C)$

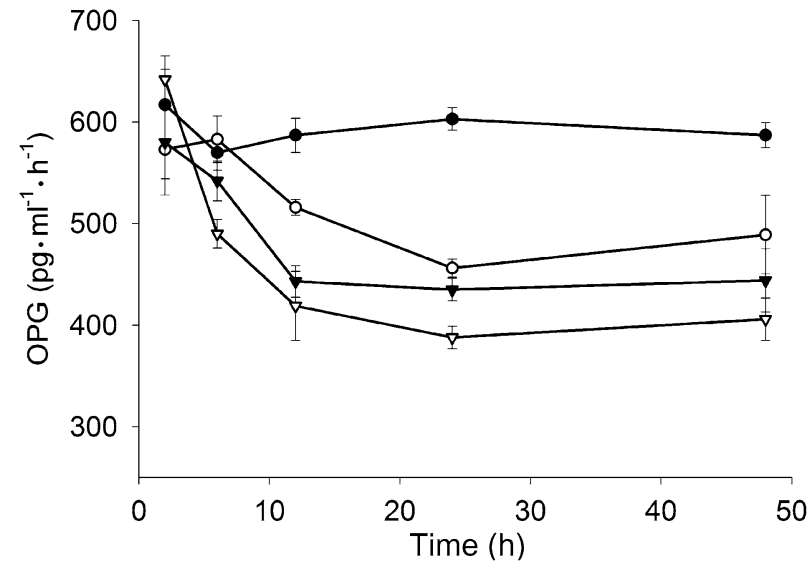

Fig. 3 Dose- and time-dependent effects of insulin on OPG production from HVSMCs. Black circles show results from cells without addition of insulin, whereas open circles are cells with $50 \mu \mathrm{U} / \mathrm{ml}$ insulin, black triangles are cells with $200 \mu \mathrm{U} / \mathrm{ml}$ insulin and open triangles are cells with $1000 \mu \mathrm{U} / \mathrm{ml}$ insulin. Results are means \pm SEM $(n=4-6)$. All values obtained with any insulin dose at 12,24 and $48 \mathrm{~h}$ are significantly different from results from cells without insulin added $(p<0.01)$

When individual samples were analysed by $\mathrm{GnHCl}$ extraction, we found that there were no differences, in terms of the extraction efficiency of total protein per milligram dry defatted tissue, between diabetic and non-diabetic samples in any of the tissue compartments (data not shown). Consequently, the OPG content is expressed as ng OPG/mg dry defatted weight. As shown in Fig. 1, a higher concentration of OPG in tunica media was observed in samples from diabetic individuals compared with in non-diabetic individuals. This was the case under both normal-appearing intima $(p<0.01)$ and plaques $(p<0.05)$. No differences between diabetic and non-diabetic subjects were observed when intimal tissue was compared. No statistically significant correlation between OPG content and age or diabetes duration was observed for any tissue compartment. Table 2

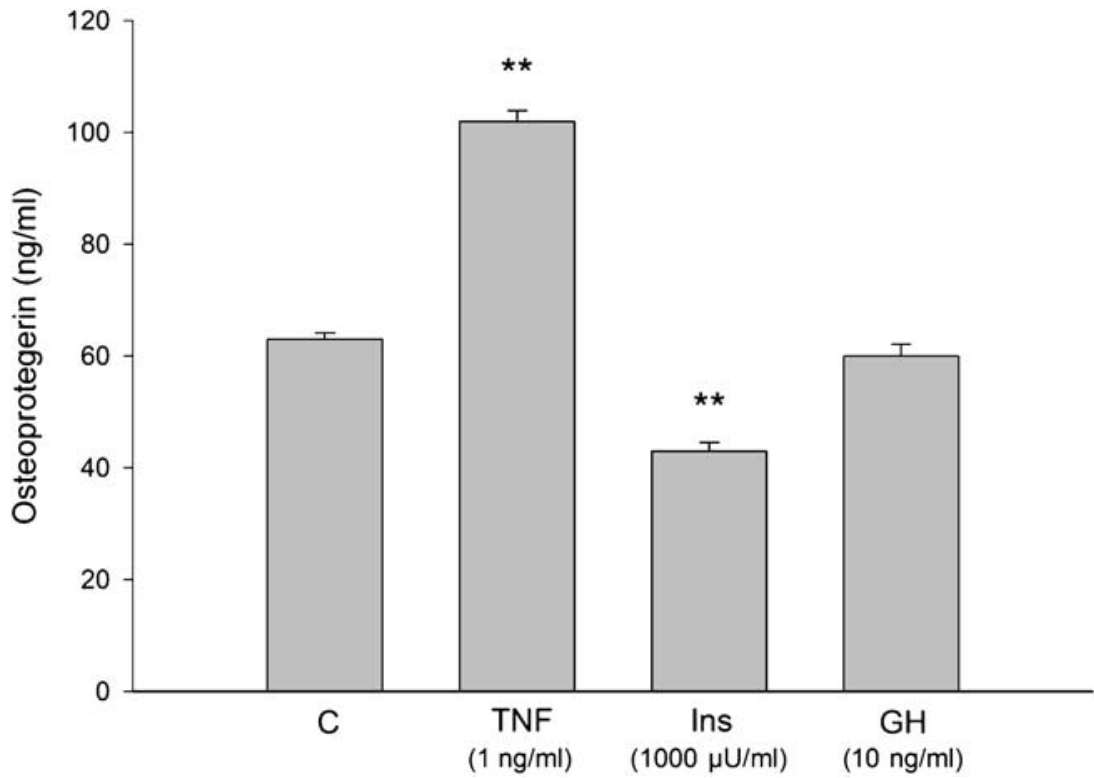


Fig. 4 Dose- and time-dependent effects of TNF- $\alpha$ on OPG production from HVSMCs.

Black circles show results from cells without addition of TNF- $\alpha$, whereas open circles are cells with $0.04 \mathrm{ng} / \mathrm{ml} \mathrm{TNF-} \alpha$ and black triangles are cells with 1 $n g / m l$ TNF- $\alpha$. Results are means \pm SEM $(n=4-6)$. All values obtained with any amount of TNF- $\alpha$ at any analysed time points are significantly different from results from control cells $(p<0.01)$

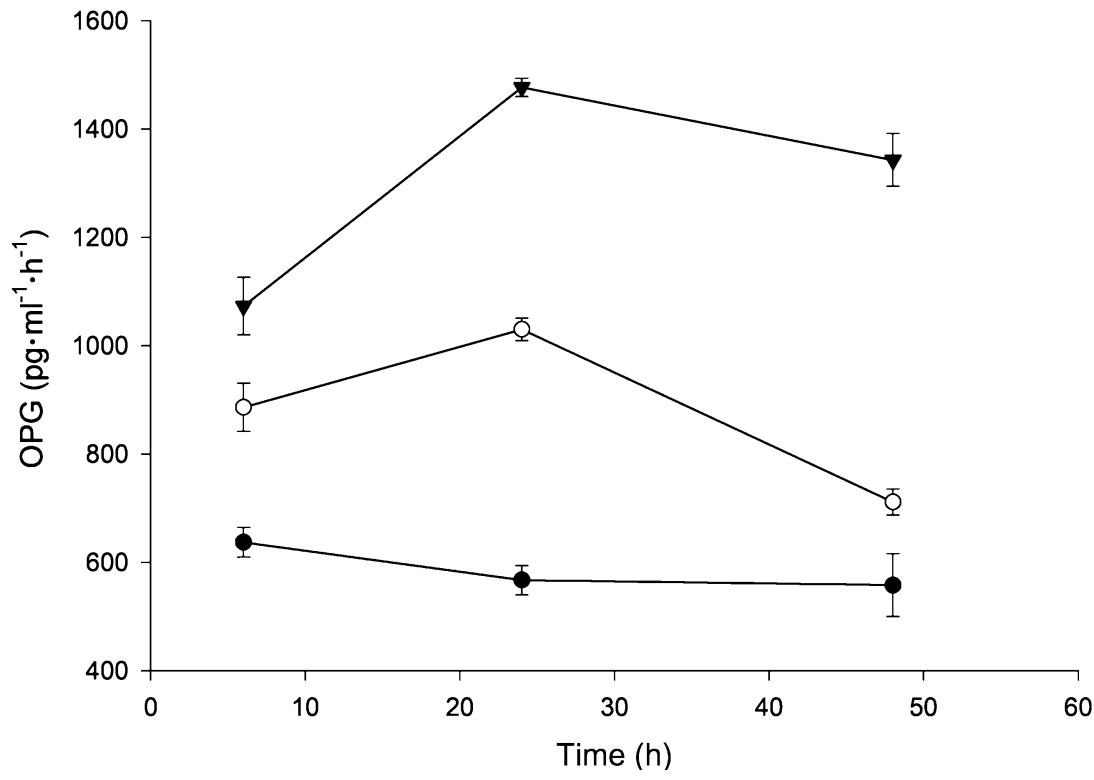

shows the separated results for type 1 and type 2 diabetes. As shown, both groups showed the same tendencies as the combined group. Some variation in the results are present and the difference between diabetic and non-diabetic individuals in normal media is particularly strong in the type 1 group. We found increased calcium contents in plaque areas compared with normal intima and media (Table 2), but no differences were seen between diabetic and non-diabetic tissue and no significant relations between OPG and calcium contents were obtained in any of the tissue compartments.

In our in vitro studies, we first observed that HVSMCs produce high amounts of OPG, whereas HUVECs produce considerably less $[93 \pm 2$ vs $3.4 \pm 0.39 \mathrm{ng} / \mathrm{ml}($ mean $\pm \mathrm{SEM}$ ), $n=6, p<0.001]$. In these experiments, HUVECs were grown with the same cell density as HVSMCs. Figure 2 depicts OPG production from HVSMCs and it is clear that this production is modifiable by insulin and TNF- $\alpha$, whereby it is significantly increased or decreased. As seen in Fig. 3, insulin addition to the medium leads to decreased secretion of OPG after 6-12 h, and the production was kept at lower levels for up to $48 \mathrm{~h}$. The effect of insulin was dependent on dose, which was as low as $50 \mu \mathrm{U} / \mathrm{ml}$. Also in the case of TNF- $\alpha$, we observed a time- and dose-dependent effect, with significantly increased values beginning at $6 \mathrm{~h}$ after the addition of the cytokine (Fig. 4). No effects on OPG production were seen when extra glucose was added to the growth medium: the concentration of OPG after $24 \mathrm{~h}$ was $62 \pm 3$ vs $59 \pm 3 \mathrm{ng} / \mathrm{ml}$ in 25 and $5.5 \mathrm{mmol} / 1$ glucose, respectively (mean \pm SEM, $n=8, p>0.1$ ). The effects of insulin and TNF- $\alpha$ on the production of OPG were paralleled by similar alterations in mRNA expression. As seen in Fig. 5, we observed decreased OPG mRNA expression after the
Fig. 5 OPG mRNA expression in HVSMCs under the influence of insulin $(1,000 \mu \mathrm{U} / \mathrm{ml})$ for 6 and $24 \mathrm{~h}$. Black circles are results from cells without the addition of insulin, and open circles are results from cells with the addition of insulin for 6 or $24 \mathrm{~h}$. Data are presented as means \pm SEM $(n=6-9)$. ${ }^{*} * p<0.01$

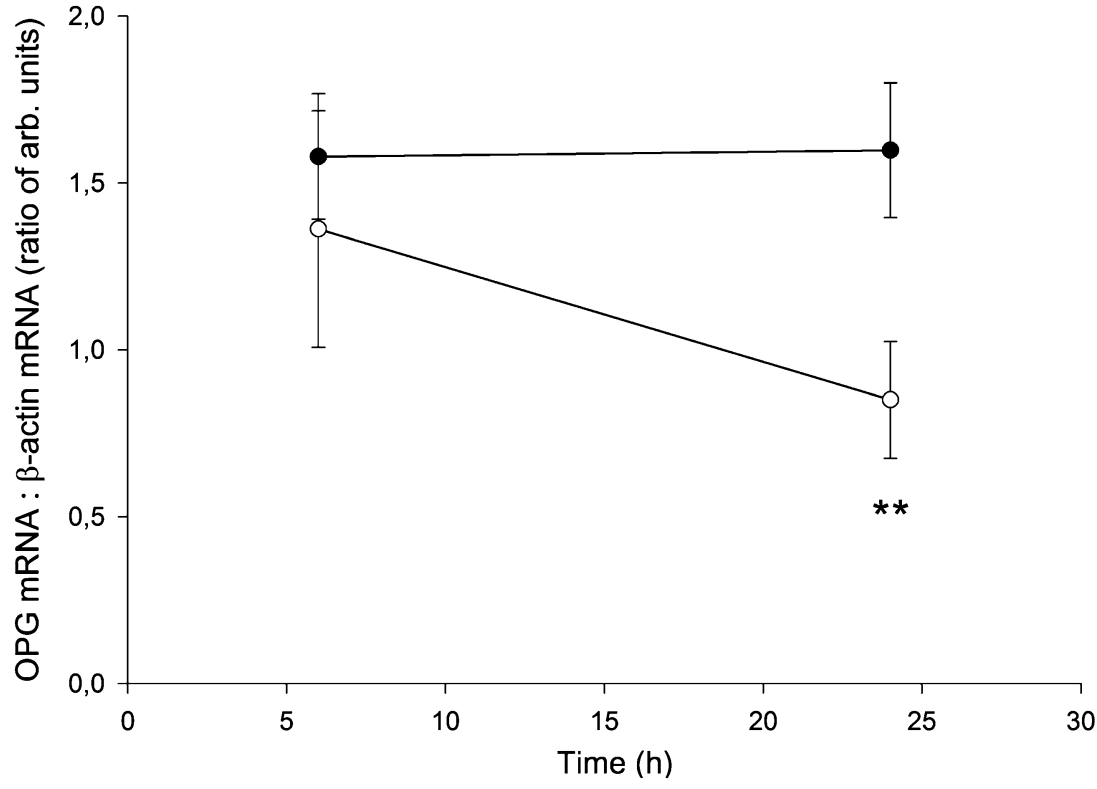


Fig. 6 OPG mRNA expression in HVSMCs under the influence of TNF- $\alpha(1 \mathrm{ng} / \mathrm{ml})$ for 6,12 and $24 \mathrm{~h}$ as indicated. Closed circles are results from cells without the addition of TNF- $\alpha$ and open circles are results from cells with the addition of TNF- $\alpha$ for 6,12 or $24 \mathrm{~h}$. Data are presented as means \pm SEM $(n=3-6) .{ }^{* *} p<0.01$

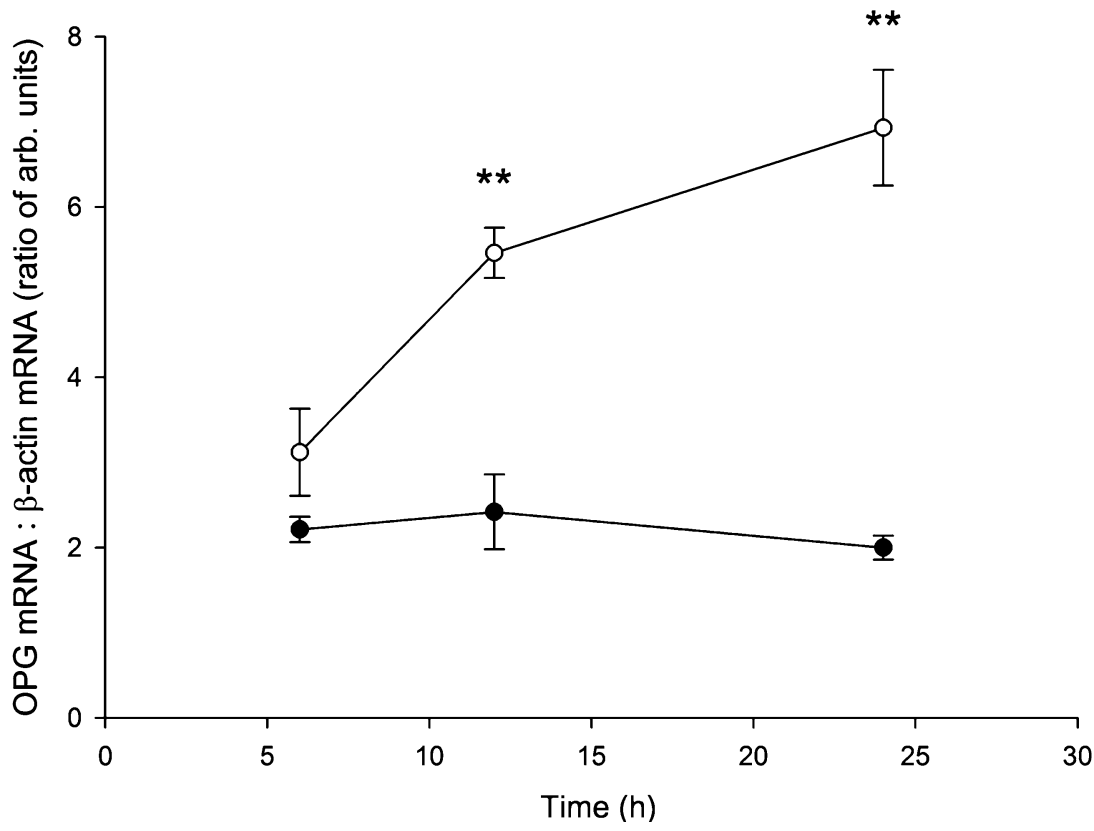

addition of insulin $(1,000 \mu \mathrm{U} / \mathrm{ml})$ to the HVSMCs. The effect was statistically significant $24 \mathrm{~h}$ after addition of the hormone. The effect of TNF- $\alpha$ on OPG mRNA expression is shown in Fig. 6 where significantly increased OPG mRNA amounts are seen 12 and $24 \mathrm{~h}$ after TNF- $\alpha$ stimulation. No effects of insulin and TNF- $\alpha$ were seen when expression of the control gene $\beta$-actin mRNA was considered.

\section{Discussion}

The present finding of increased OPG concentrations in the aortic media fits well with earlier observations of altered matrix components in the arterial wall in diabetes. As in previous investigations, we found changes in the tunica media, notably in both normal and atherosclerotic parts of the vessel wall [3, 4]. Interestingly, osteopontin [16] and mRNA for bone-Gla-protein [18] were recently found in increased amounts in arterial tissue from a few patients with diabetes. Together, these results and the present data are compatible with the notion that accumulation of bonerelated substances may be a feature of diabetic macroangiopathy.

No previous studies have quantitated the amounts of OPG in the arterial wall. Compared with the concentration of OPG in plasma we found that the content in aorta is approximately 500 times higher [29] (assuming a water content of arterial tissue of $80 \%$ [4]) and is at a level similar to that reported for bone [30]. We found that the most efficient extraction procedure was seen with solutions containing $\mathrm{GnHCl}$. This could indicate that OPG is associated with anionic low-solubility components of the vascular wall, for example proteoglycans, which is consistent with the fact that OPG contains a heparin-binding domain [33].

A recent publication indicates that the amount of OPG in atherosclerotic plaques may differ with plaque type (stable vs unstable) [34]. However, it is important to note that the present investigation of arterial tissue was primarily designed to study possible generalised differences between diabetic and non-diabetic vessels. The apparent lack of difference between atherosclerotic vs non-atherosclerotic and intima vs media compartments of the vessel wall with respect to OPG concentrations in our study should therefore be interpreted with caution. Large local differences in OPG amounts at the cellular level, for example in relation to specific areas with apoptotic cells or calcifications, etc. as previously indicated [35], may be overlooked with the present research design. Elucidation of such putative relations demands alternative study designs. Also in this respect, it should be noted that the separation of media and intima was done rather crudely, which could give rise to a mixing of the two layers.

Another limitation of the present study relates to the lack of statistically significant correlations between arterial OPG concentrations in the arterial compartments and both age and diabetes duration. This is in light of the fact that both the average age and duration of diabetes are rather high and that the ranges of these parameters are narrow. Nevertheless, these limitations do not influence our basic finding of higher average OPG concentrations in the deeper layers of the aortic wall in diabetes.

It has been suggested that OPG is an inhibitor of arterial calcification, since OPG deficiency leads to calcifications in the aorta and the renal arteries in an experimental model [23]. This notion is not really consistent with the present finding of increased OPG levels in arteries from individuals with diabetes, which often display linear arterial calcifications. Several aspects regarding this discrepancy should, however, be taken into consideration. One explanation could be that OPG is upregulated to compensate for the presence of calcifications in diabetes. However, we did not find altered calcium content in the aortic media, in line with the fact that this vessel is not known to harbour roentgenologically detectable media calcifications in diabetes. The 
OPG levels and putative relations to calcium content could, however, differ in other areas of the arterial tree, where media calcifications are present. Another consideration relates to the fact that OPG is only one of several calcification-modifying molecules. Alterations in other calcification inhibitors and activators could play a more dominant role than OPG in the arterial wall in diabetes. Also, the concept of OPG as an inhibitor of vascular calcifications may be more complex than the initial experimental studies imply. For example, alternative explanations that downplay the direct effects of OPG on arterial calcifications in the experiments with OPG knock-out animals but emphasise secondary arterial effects due to the influence of OPG on bone resorption have been put forward [24]. Moreover, the experimental data regarding OPG functionality were obtained in mice, where the mechanisms leading to vascular calcifications may be different from the processes in humans. Although the function of OPG in the vasculature is thus debatable, the present finding is compatible with the idea that bone-related molecules, such as OPG, are upregulated in the arterial wall in diabetes and that such alterations may hypothetically relate to the development of medial calcifications.

Accumulation of OPG in the arterial wall may be caused by altered production of the molecule by HVSMCs, which produce large amounts of the molecule. The regulation of OPG production from HVSMCs has previously been shown to be influenced by platelet-derived growth factor [25] and activators of peroxisome proliferator-activated receptor [36]. In the present study, we observed that OPG secretion is regulated by two other factors, i.e. insulin and TNF- $\alpha$, which may be relevant for the accumulation of OPG in arteries in diabetes. Our insulin results expand the repertoire of reported insulin effects in HVSMCs, which earlier mostly comprised effects on proliferative and migratory functions. However, an additional influence on the secretion of extracellular molecules has been observed and, in line with the current data, we previously reported that insulin decreases the production of the cartilage-related molecule hyaluronan [31]. The role of insulin in the development of macrovascular disease is, however, not clear and at present it is not known whether lack of insulin activity and/or increased insulin action play significant roles in the vasculature in diabetes. Our data are compatible with the idea that lack of insulin action (either because of insulin resistance in type 2 diabetes or periodical lack of insulin peptide in type 1 diabetes) may be part of the mechanism behind the accumulation of OPG. Clearly, many other factors could also play a role, and interestingly, we found that TNF- $\alpha$ strongly induces OPG production. TNF- $\alpha$ is best known for its pro-inflammatory activities, but it has also been implicated in the development of vascular calcifications since it is capable of inducing bonetype alkaline phosphatase in HVSMCs [37]. TNF- $\alpha$ has moreover been found in increased amounts in the plasma of patients with both type 1 [38] and type 2 diabetes [39, 40] and a role for TNF- $\alpha$ in OPG accumulation in diabetes is possible. Direct effects of high glucose concentrations and increased growth hormone levels have been implicated in the development of macrovascular disease in diabetes. The present results do not support the idea that these factors are directly involved in the accumulation of OPG.

Three independent studies have described increased plasma concentrations of OPG among patients with diabetes. In one report, high values of OPG were seen in a subgroup of diabetic women in a study primarily examining the relation between plasma OPG and bone density and fracture rates [27]. In another investigation of $522 \mathrm{men}$, which describes a positive relation between coronary arteriosclerosis (determined by coronary angiography) and plasma OPG, it was reported that diabetic men had elevated plasma levels of OPG. The increase was independent of the degree of coronary sclerosis [28]. More recently, we found in a cross-sectional study of approximately 100 individuals, that patients with type 2 diabetes, especially those with microvascular manifestations, display increased values of OPG [29]. Data from the present study fit well with these reports, and it can be hypothesised that increased levels of plasma OPG in diabetes may reflect arterial accumulation of the molecule.

In conclusion, we have observed increased levels of OPG in the aortic tunica media among patients with diabetes. The OPG accumulation represents a case of upregulation of a bone-related component in the vascular tree in diabetes, putatively related to the development of media calcifications. Altered OPG concentrations in the arterial tissue may be the result of the effects of insulin and TNF- $\alpha$ on the production of this molecule from vascular smooth muscle cells. By investigating OPG and other bone-related molecules in relation to the arterial wall, we would gain a new perspective on the understanding of the molecular mechanisms underlying the development of macrovascular disease in diabetes.

Acknowledgements The technical assistance of A. L. Larsen is greatly appreciated. The present study was supported by the Danish Medical Association Research Fund, the Danish Heart Foundation, the Danish Medical Research Council and the Danish Diabetes Association.

\section{References}

1. Andresen JL, Rasmussen LM, Ledet T (1996) Diabetic macroangiopathy and atherosclerosis. Diabetes 45(Suppl 3):S91S94

2. Dybdahl H, Ledet T (1987) Diabetic macroangiopathy. Quantitative histopathological studies of the extramural coronary arteries from type 2 (non-insulin-dependent) diabetic patients. Diabetologia 30:882-886

3. Rasmussen LM, Heickendorff L (1989) Accumulation of fibronectin in aortas from diabetic patients. A quantitative immunohistochemical and biochemical study. Lab Invest 61:440 446

4. Rasmussen LM, Ledet T (1993) Aortic collagen alterations in human diabetes mellitus. Changes in basement membrane collagen content and in the susceptibility of total collagen to cyanogen bromide solubilisation. Diabetologia 36:445-453

5. Sims TJ, Rasmussen LM, Oxlund H, Bailey AJ (1996) The role of glycation cross-links in diabetic vascular stiffening. Diabetologia 39:946-951 
6. De Vriese AS, Verbeuren TJ, Van de Voorde J, Lameire NH, Vanhoutte PM (2000) Endothelial dysfunction in diabetes. Br J Pharmacol 130:963-974

7. Oxlund H, Rasmussen LM, Andreassen TT, Heickendorff L (1989) Increased aortic stiffness in patients with type 1 (insulindependent) diabetes mellitus. Diabetologia 32:748-752

8. Neubauer B (1971) A quantitative study of peripheral arterial calcification and glucose tolerance in elderly diabetics and nondiabetics. Diabetologia 7:409-413

9. Young MJ, Adams JE, Anderson GF, Boulton AJ, Cavanagh PR (1993) Medial arterial calcification in the feet of diabetic patients and matched non-diabetic control subjects. Diabetologia 36:615-621

10. Lehto S, Niskanen L, Suhonen M, Ronnemaa T, Laakso M (1996) Medial artery calcification. A neglected harbinger of cardiovascular complications in non-insulin-dependent diabetes mellitus. Arterioscler Thromb Vasc Biol 16:978-983

11. Niskanen L, Siitonen O, Suhonen M, Uusitupa MI (1994) Medial artery calcification predicts cardiovascular mortality in patients with NIDDM. Diabetes Care 17:1252-1256

12. Chen NX, Moe SM (2003) Arterial calcification in diabetes. Curr Diabetes Rep 3:28-32

13. Bostrom K, Watson KE, Horn S, Wortham C, Herman IM, Demer LL (1993) Bone morphogenetic protein expression in human atherosclerotic lesions. J Clin Invest 91:1800-1809

14. Speer MY, McKee MD, Guldberg RE et al (2002) Inactivation of the osteopontin gene enhances vascular calcification of matrix Gla protein-deficient mice: evidence for osteopontin as an inducible inhibitor of vascular calcification in vivo. J Exp Med 196:1047-1055

15. Luo G, Ducy P, McKee MD et al (1997) Spontaneous calcification of arteries and cartilage in mice lacking matrix GLA protein. Nature 386:78-81

16. Takemoto M, Yokote K, Nishimura M et al (2000) Enhanced expression of osteopontin in human diabetic artery and analysis of its functional role in accelerated atherogenesis. Arterioscler Thromb Vasc Biol 20:624-628

17. Heickendorff L, Ledet T, Rasmussen LM (1994) Glycosaminoglycans in the human aorta in diabetes mellitus: a study of tunica media from areas with and without atherosclerotic plaque. Diabetologia 37:286-292

18. Shanahan CM, Cary NR, Salisbury JR, Proudfoot D, Weissberg PL, Edmonds ME (1999) Medial localization of mineralizationregulating proteins in association with Monckeberg's sclerosis: evidence for smooth muscle cell-mediated vascular calcification. Circulation 100:2168-2176

19. Towler DA, Bidder M, Latifi T, Coleman T, Semenkovich CF (1998) Diet-induced diabetes activates an osteogenic gene regulatory program in the aortas of low density lipoprotein receptor-deficient mice. J Biol Chem 273:30427-30434

20. Tse J, Martin-McNaulty B, Halks-Miller M et al (1999) Accelerated atherosclerosis and premature calcified cartilaginous metaplasia in the aorta of diabetic male Apo E knockout mice can be prevented by chronic treatment with 17 betaestradiol. Atherosclerosis 144:303-313

21. Simonet WS, Lacey DL, Dunstan CR et al (1997) Osteoprotegerin: a novel secreted protein involved in the regulation of bone density. Cell 89:309-319

22. Min H, Morony S, Sarosi I et al (2000) Osteoprotegerin reverses osteoporosis by inhibiting endosteal osteoclasts and prevents vascular calcification by blocking a process resembling osteoclastogenesis. J Exp Med 192:463-474

23. Bucay N, Sarosi I, Dunstan CR et al (1998) Osteoprotegerindeficient mice develop early onset osteoporosis and arterial calcification. Genes Dev 12:1260-1268

24. Price PA, June HH, Buckley JR, Williamson MK (2001) Osteoprotegerin inhibits artery calcification induced by warfarin and by vitamin D. Arterioscler Thromb Vasc Biol 21:1610-1616
25. Zhang J, Fu M, Myles D et al (2002) PDGF induces osteoprotegerin expression in vascular smooth muscle cells by multiple signal pathways. FEBS Lett 521:180-184

26. Malyankar UM, Scatena M, Suchland KL et al (2000) Osteoprotegerin is an alpha vbeta 3-induced, NF-kappa B-dependent survival factor for endothelial cells. J Biol Chem 275:2095920962

27. Browner WS, Lui LY, Cummings SR (2001) Associations of serum osteoprotegerin levels with diabetes, stroke, bone density, fractures, and mortality in elderly women. J Clin Endocrinol Metab 86:631-637

28. Schoppet M, Sattler AM, Schaefer JR, Herzum M, Maisch B, Hofbauer LC (2003) Increased osteoprotegerin serum levels in men with coronary artery disease. J Clin Endocrinol Metab 88:1024-1028

29. Knudsen ST, Foss CH, Poulsen PL, Andersen NH, Mogensen CE, Rasmussen LM (2003) Increased plasma concentrations of osteoprotegerin in type 2 diabetic patients with microvascular complications. Eur J Endocrinol 149:39-42

30. Ueland T, Brixen K, Mosekilde L, Mosekilde L, Flyvbjerg A, Bollerslev J (2003) Age-related changes in cortical bone content of insulin-like growth factor binding protein (IGFBP)-3, IGFBP5 , osteoprotegerin, and calcium in postmenopausal osteoporosis: a cross-sectional study. J Clin Endocrinol Metab 88:1014-1018

31. Erikstrup C, Pedersen LM, Heickendorff L, Ledet T, Rasmussen LM (2001) Production of hyaluronan and chondroitin sulphate proteoglycans from human arterial smooth muscle- the effect of glucose, insulin, IGF-I or growth hormone. Eur J Endocrinol 145:193-198

32. Rasmussen LM, Hansen PR, Nabipour MT, Olesen P, Kristiansen MT, Ledet T (2001) Diverse effects of inhibition of 3-hydroxy-3-methylglutaryl-CoA reductase on the expression of VCAM-1 and E-selectin in endothelial cells. Biochem J 360:363-370

33. Yamaguchi K, Kinosaki M, Goto M et al (1998) Characterization of structural domains of human osteoclastogenesis inhibitory factor. J Biol Chem 273:5117-5123

34. Golledge J, McCann M, Mangan S, Lam A, Karan M (2004) Osteoprotegerin and osteopontin are expressed at high concentrations within symptomatic carotid atherosclerosis. Stroke 35:1636-1641

35. Tyson KL, Reynolds JL, McNair R, Zhang Q, Weissberg PL, Shanahan CM (2003) Osteo/chondrocytic transcription factors and their target genes exhibit distinct patterns of expression in human arterial calcification. Arterioscler Thromb Vasc Biol 23:489-494

36. Fu M, Zhang J, Lin YY, Zhu X, Willson TM, Chen YE (2002) Activation of peroxisome proliferator-activated receptor gamma inhibits osteoprotegerin gene expression in human aortic smooth muscle cells. Biochem Biophys Res Commun 294:597-601

37. Shioi A, Katagi M, Okuno Y et al (2002) Induction of bonetype alkaline phosphatase in human vascular smooth muscle cells: roles of tumor necrosis factor-alpha and oncostatin $\mathrm{M}$ derived from macrophages. Circ Res 91:9-16

38. Lechleitner M, Koch T, Herold M, Dzien A, Hoppichler F (2000) Tumour necrosis factor-alpha plasma level in patients with type 1 diabetes mellitus and its association with glycaemic control and cardiovascular risk factors. J Intern Med 248:67-76

39. Nilsson J, Jovinge S, Niemann A, Reneland R, Lithell H (1998) Relation between plasma tumor necrosis factor-alpha and insulin sensitivity in elderly men with non-insulin-dependent diabetes mellitus. Arterioscler Thromb Vasc Biol 18:1199-1202

40. Winkler G, Salamon F, Harmos G et al (1998) Elevated serum tumor necrosis factor-alpha concentrations and bioactivity in Type 2 diabetics and patients with android type obesity. Diabetes Res Clin Pract 42:169-174 